\title{
MQL 加工における工具温度分布の測定 Tool Temperature Measurement in MQL Machining
}

\author{
○学 大橋輝彰(岐阜大院) 正 加藤隆雄(岐阜大)
}

Teruaki Ohashi , Gifu University, 1-1Yanagido, Gifu Takao KATO, Gifu University, 1-1Yanagido, Gifu

Key Words: Temperature measurement, MQL, PVD(physically vapor deposited) film, Turning, Cutting tool

\section{1. はじめに}

環境保護および廃油処理コストの削減,さらには工具の長寿命 化のため MQL 加工が注目されてきている.この加工法は高速ミ ーリングによる金型加工や小径深穴加工などの限られた加工分 野ではその有効性が確かめられているが, 発熱量の著しい旋削 においては十分な効果が得られていない.これまで MQL の評価 は主に工具摩耗の観点からその有効性が評価されてきているが, その測定が困難であるため工具温度を直接測定して MQL 加工 の有效性を確認した研究は見当たらない.

本研究では, 油性および水溶性オイルミストを使用した MQL 旋削加工中の工具温度分布を“PVD 薄膜法”により直接測定し, 極微量の切削液が工具温度分布や切削抵抗にどのような影響を 及ぼすかを明らかにすること目的とした。

\section{2. 実験方法}

薄膜がその固有の融点に達すれば融解するといら物理現象を 利用して, 固体内部の温度分布を測定する方法が PVD 薄膜法で ある. (1)この方法を使用して旋削加工における工具刃先の温度分 布を測定する手順を以下に説明する.

一定厚さの円盤状材料をチャックに取り付け，直線切れ刃を半 径方向に送って2次元切削を行う.この工具刃先は切削方向に平 行に分割してある.この分割面に融点が既知の物質の薄膜を真 空蒸着(膜厚 $0.1 \mu \mathrm{m}$ 程度し,この面が切削幅の中心に位置する ように位置決めして切削実験を行うここのように薄膜を間に挟んだ 工具で一定時間切削加工を行い, 加工終了後, 刃先部分を取り 出し分割面をマイクロスコープで観察すると, 図 1 のような薄膜に 境界線が現れるのが認められる.この境界線は刃先付近の薄膜 が一度溶融して固まった領域と薄膜の溶融が全く生じなかった領 域の境界になる.この境界線上の温度は薄膜の融点この図では Bi の融点 $\left.271^{\circ} \mathrm{C}\right)$ と一致するとみなすことができる.したがって, 数 種類の異なる融点の薄膜を使用して同様の実験を繰り返せば, 工具内部の温度分布を明らかにすることができる.

切削抵抗 2 分力 (主分力 $F_{b}$, 背分力 $F_{v}$ ) は圧電式 3 成分動力計 (KISTLER 9257B)で測定した. NC 旋盤(Okuma LS-30)のプログラ 厶運転により一定の切削速度 $(100 \mathrm{~m} / \mathrm{min})$ と送り $(0.1 \mathrm{~mm} / \mathrm{rev})$ を与 えた.使用した工具は超硬 K10 である. 使用した 3 種類の薄膜材 料はインジウム, ビスマス, テルルで, その公称融点を表 1 に示す. 被削材はチタン合金(Ti-6Al-4V) で板厚は $2.5 \mathrm{~mm}$ である.

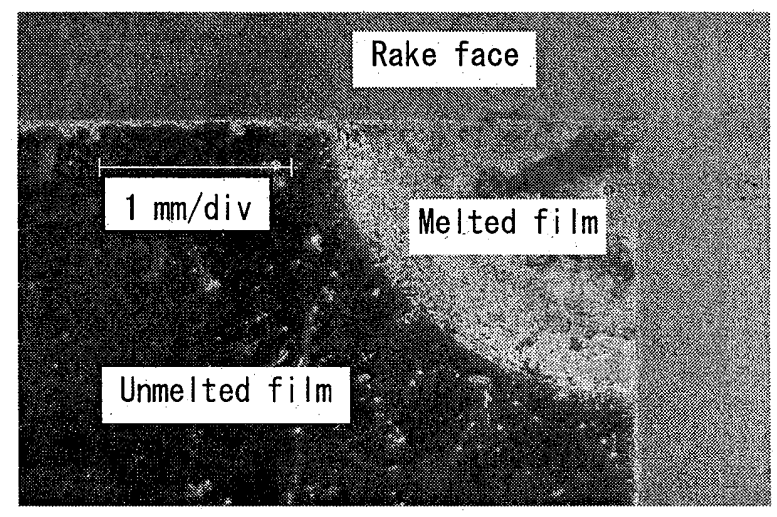

Fig.1 Photomicrograph of PVD film (Bismuth)

Table1 PVD film materials

\begin{tabular}{|c|c|c|c|}
\hline PVD film & In & $\mathrm{Bi}$ & $\mathrm{Te}$ \\
\hline Melting point $\left({ }^{\circ} \mathrm{C}\right)$ & 157 & 271 & 450 \\
\hline
\end{tabular}

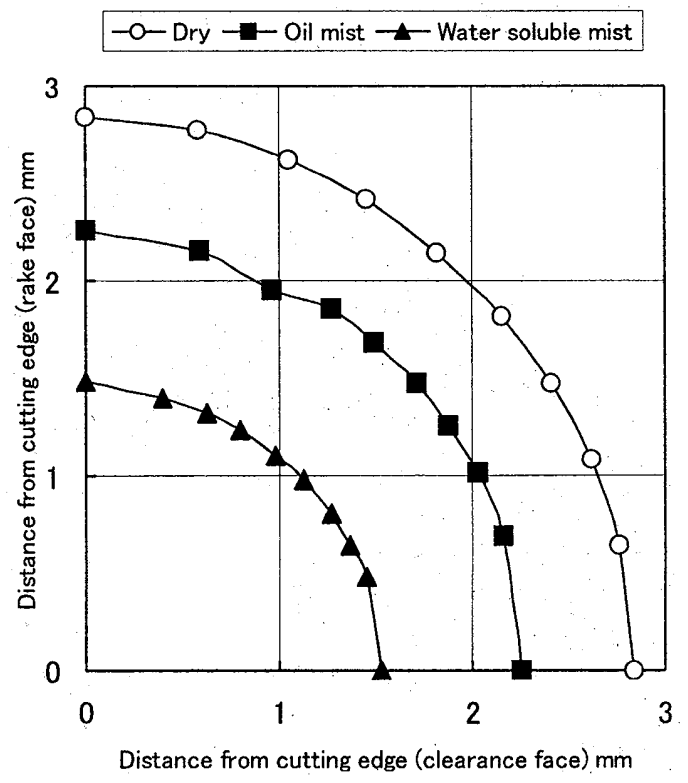

Fig.2 Isothermal line of $157^{\circ} \mathrm{C}$ 
ミストの供給はセミドライクーラントミスト装置 PK1-334(フジ BC 技研)を使用し，専用ノズルを設けた工具ホルダにより工具すくい 面と逃げ面にピンポイントに供給した.ミミストは油性切削油(ブル 一ベ LB-1) と水溶性切削油(フィリウム 621) でそれぞれの吐出 量は $70 \mathrm{ml} / \mathrm{h}, 2100 \mathrm{ml} / \mathrm{h}$ である.

\section{3. 実験結果}

\section{1 連続切削}

工具刃先内部の等温線 $\left(157^{\circ} \mathrm{C}\right)$ の測定結果の一例を図 2 に示す．乾式切削に比べ油性オイルミストにより工具温度は 低下し，水溶性ミストではさらに温度が低下しその冷却効果 が明らかに認められる。

図 3 は測定された等温線から工具すくい面の温度分布を求 めた結果である。油性ミスと,水溶性ミストともに乾式に比べ すくい面の温度が全体に低下している，特に水溶性ミスとの 冷却効果が著しい。

3 種類の切削方式に対して得られた主分力 $F_{h}$ と背分力 $F_{v}$ の測 定結果を図4に示寸. 乾式, 油性才イルミスト,水溶性オイルミストに よる切削抵抗は主分力,背分力ともほとんど変化がなく,油性およ び水溶性いずれのオイルミストもすくい面の潤滑作用は認められ ない.

\section{2 断続切削}

断続切削では円盤状被削材の円周上の 2 䇢所に切り欠きを入 れ，1/4 回転ごとに切削,空転を交互に繰り返方方式の実験を行 った.連続切削の場合と同様にすくい面の温度分布を測定した 結果を図 5 に示す. 断続切削の場合は連続切削に比べ切削に よる消費エネルギがほぼ半分になるため, 工具全体の温度が 低下している，油性オイルミストと水溶性オイルミストの冷 却効果は認められるが, 連続切削に比較するとわずかである. また，低温領域では冷却効果が認められるが高温領域になる と冷却効果はなくなる。

断続切削の切削抵抗の測定結果を図 6 に示す. 連続切削の 場合と同様に，油性オイルミスト，水溶性オイルミストを使 用しても抵抗は乾式切削の場合とほとんど変わらず，ミスト のすくい面潤滑作用は認められない。

\section{4. おわりに}

旋削加工におけるミスト潤滑の効果を確かめるため, PVD 薄膜 法によりチタン合金を旋削中の工具刃先の温度分布を実測して 以下のことを明らかにした。

（1）連続切削, 断続切削ともに油性オイルミスト, 水溶性オイ ルミストによる切削抵抗は乾式切削とほぼ同じですくい面 潤滑作用は認められない。

（2）連続切削においてミストの泠却作用は認められ，水溶性ミ ストの冷却効果は大きい. 断続切削において冷却効果は 認められるが, 連続切削に比べその効果は小さい.

\section{参考文献}

(1) T.Kato, H.Fujji, PVD Film Method for Measuring the Temperature Distribution in Cutting Tools, Trans.ASME, Journal of Engineering for Industry, 118, (1996), 117-122.

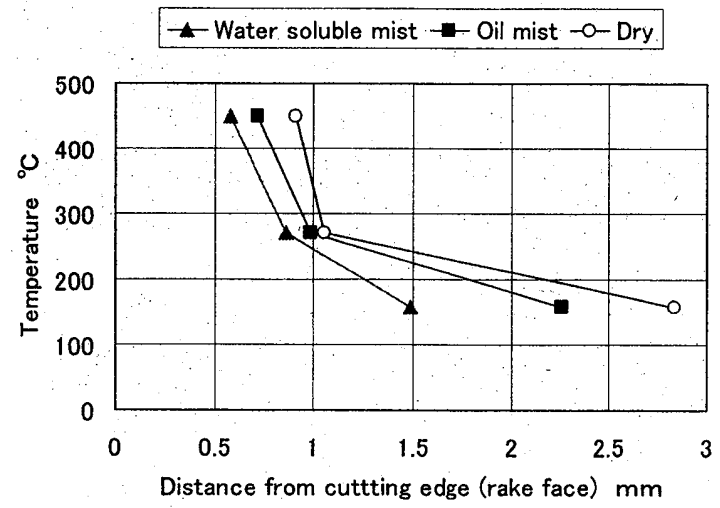

Fig.3 Temperature distribution (rake face)

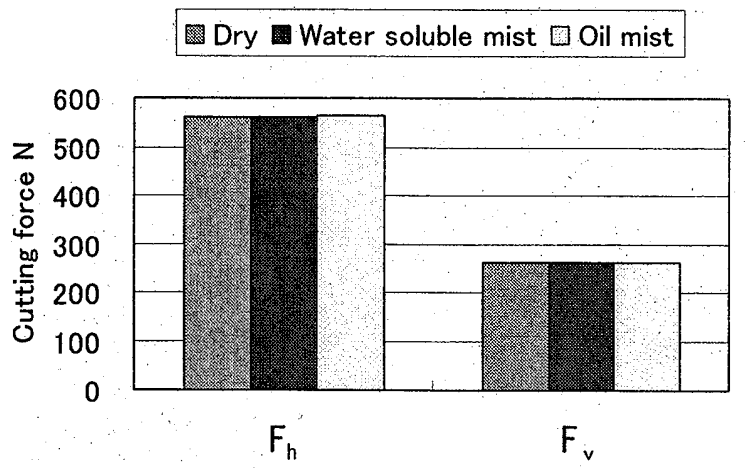

Fig.4 Cutting force (Continuous cutting)

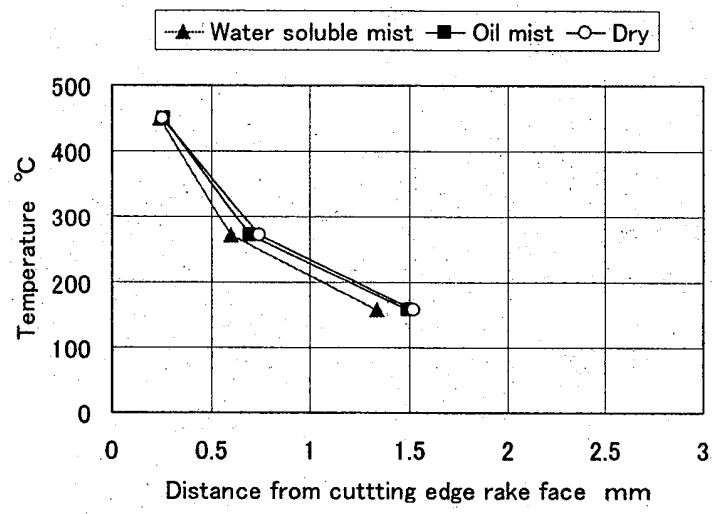

Fig.5 Temperature distribution (rake face)

Dry Water soluble mist $\square$ Oil mist

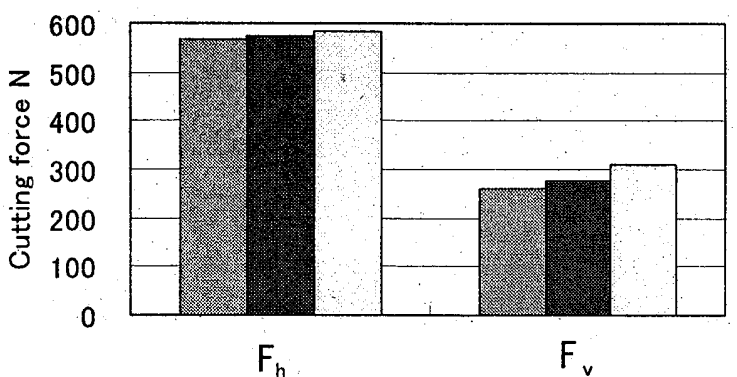

Fig6 Cutting force (Intermittent cutting) 